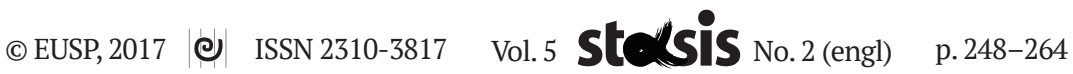

\title{
10
}

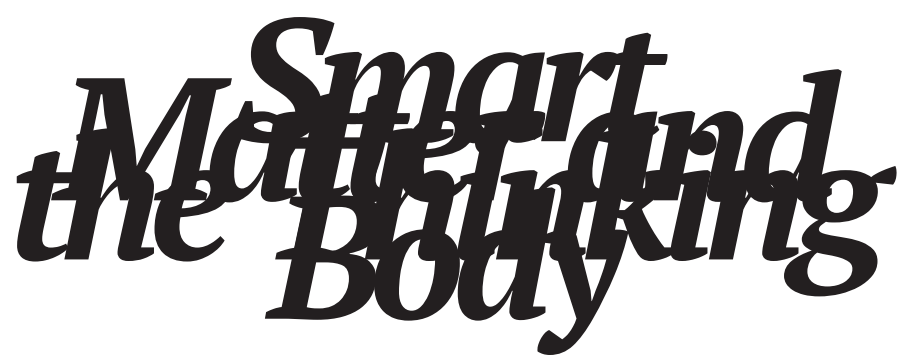

Alex Levant

Wilfrid Laurier University

\section{Smart Matter and the Thinking Body: Activity Theory and the Turn to Matter in Contemporary Philosophy}

\begin{abstract}
This article seeks to excavate and mobilize Activity Theory (AT)

for a conversation with recent trends in contemporary philosophy that attempt to overcome the relativism of the linguistic turn while accepting the latter's core critique of Enlightenment conceptions of the human and nonhuman. Specifically, it focuses on Ilyenkov's concept of the thinking body as a useful contrast to the ascription of agency to matter, and instead helps to illuminate the social practices that animate the material world.
\end{abstract}

Keywords Activity Theory, material turn, Ilyenkov, posthuman, agency 


\section{Introduction: Activity Theory and the Material Turn}

The Soviet Union was a creature of the twentieth century; however, it continues to "live" in the now in the form of ruins whose significance remains contested, threatening to form new constellations within present concerns or to disappear forever. Among these ruins, contemporary theorists with a discerning eye have discovered significant "cultural treasures" (Benjamin 2003 [1940]), yet many remain buried deep in layers of opaque political and philosophical debates (Levant 2008, 2011). Among these gems lies a theoretical tradition-broadly known as Activity Theory ${ }^{1}$ (AT) - that resonates strongly with certain trends in contemporary philosophy.

AT originated as a radical current in Soviet psychology of the 1920s. Its core proposal is that human subjectivity is not reducible to the functions of the physical brain or even the individual body more broadly, nor is it essentially a discursive phenomenon that can be explained using theories of the "linguistic turn." In contrast, AT posits the human subject as always-embedded in object-oriented social practices (Leontiev 1978; Stetsenko 2013; Kaptelinin 2005). This turn to the material (in the form of objective human activity) situates AT in close proximity to the "material turn" in contemporary philosophy, although very little work has been done to place these bodies of thought in dialogue.

The "material turn" refers to a broad range of recent philosophical trends, including new materialism (Braidotti 2013; Barad 2012; Dolphijn and van der Tuin 2012), actor-network theory (Latour 1992, 2005), and postphenomenology (Rosenberger and Verbeek 2015; Ihde 2010; Verbeek 2005), among others. While quite different in many respects, these approaches share a common concern to overcome the perceived limits of the linguistic turn. Accepting a core critique of anthropocentrism, they invite us, in various ways, to rethink the nature of the human and the nonhuman, and to situate the human not as the subject at the center of a world of objects, but as always embedded in a material world that is, in some ways, alive, thinking, and acting.

Similar to theoretical currents of the material turn, AT also substantively departs from dualist and essentialist conceptions of the human, at the same time as it offers a powerful critique of the linguistic turn. Moreover, it also signals a turn to matter, albeit it offers a different type of materialism. In addition to acknowledging that matter "matters" (Law

\footnotetext{
"Activity theory is a commonly accepted name for a line of theorizing and research initiated by the founders of the cultural-historical school of Russian psychology, L.S. Vygotsky, A.N. Leont'ev, and A.R. Luria, in the 1920s and 1930s. This approach has been elaborated further by a large number of contemporary scholars both in the former socialist countries and in the West” (Engeström and Miettinen 1999: 1).
} 
2010), AT also acknowledges the "peculiar objectivity" (Ilyenkov 2012 [2009]) of human activity, and offers a fresh perspective on "how matter comes to matter" (Barad 2007). As Karen Barad writes, "Matter and meaning are not separate elements. They are inextricably fused together, and no event, no matter how energetic, can tear them asunder" (2007: 1). To this, contemporary AT scholars (Stetskenko 2013; Engeström 1999) would add that not only are matter and meaning inseparable, but their inseparability is also inseparable from human activity.

The following article seeks to excavate AT and place it in conversation with the material turn in contemporary philosophy. Running through the various theoretical currents that comprise the material turn is the notion that matter is, in various ways, intelligent or alive. In contrast to this notion of smart matter, this article draws on Evald Ilyenkov's concept of the thinking body (mysliashchee telo) (2014: 41-42), which centers on the materiality of human activity, its "special reality" with a "peculiar objectivity." This shift is significant because it illuminates the mode ${ }^{2}$ of organizing human activity today, that is, capitalism.

\section{Activity Theory: An Introduction}

Activity Theory (AT) refers to a methodological approach used in a number of specialized fields in the social sciences around the world today. Originating as a current in Soviet psychology in the 1920s that was subsequently suppressed by the Soviet state, AT nevertheless became influential far beyond its original geographical and disciplinary context. The various branches of AT, however, grew in very different directions in a variety of disciplines around the world, making significant contributions in disparate fields, such as disability education (Bøttcher and Dammeyer 2016; Meshcheryakov 1974), organizational theory and workplace management (Engeström 1987), cross-cultural psychology (Cole 1998), human-computer interaction (Kaptelinin and Nardi 2006), labor studies (Sawchuck 2007), developmental psychology (Hedegaard and Fleer 2008), social movement theory (De Smet 2015), anthropology (Hasse 2015), therapy and addiction (Nissen and Barington 2016), and philosophy (Maidansky and Oittinen 2016; Mareev 2008), among others.

Perhaps the most remarkable of its real-world accomplishments is the application of AT in assisting four deaf-blind children to acquire undergraduate degrees at Moscow State University in 1976-a level of

2 Following Marx, I use the concept mode of production to refer to much more than an economic system. Because matter and meaning are understood as inseparable from human activity, the mode of organization of activity conditions "the social, political and intellectual life process in general” (Marx 1859), and represents a "mode of life” (Marx 1991 [1846]). 
achievement previously unattained (with singular exceptions, like American writer and political activist Helen Keller). Using a methodological approach associated with AT, Soviet psychologist Alexander Meshcheryakov (a student of Alexander Luria-one of the founders of AT) developed successful pedagogical strategies in the context of the so-called Zagorsk Experiments-his work with a group of pupils at the Zagorsk children's home for the deaf-blind (Meshcheryakov 1974). Proceeding from one of the fundamental propositions of AT-that cognitive development always occurs intersubjectively or socially first and is subsequently internalized by individuals (Vygotsky 1978) - he was able to grasp the significance of deaf-blindness as twofold: children who are deaf-blind cannot readily have access to both the physical world as well as the social world, that is, to the social experience required for cognitive development. Meshcheryakov devised alternative pedagogical methods that had the effect of simulating social experiences that facilitate mental development, establishing a sense of self and others, as well as a capacity to navigate the social world. Meshcheryakov recognized that in addition to these considerable practical achievements, AT allows us to explore questions "that go beyond the narrow confines of deaf-blindness, such as the formation of [...] the human mind" (Meshcheryakov 2009: 6).

Some of this work (notably Vygotsky 1978) became available in English for the first time in the 1970s, inspiring a new generation of theorists outside of the Soviet Union to deploy and develop this method in entirely new directions. Cole's contributions on "microcultures" (i.e., after-school programs designed to promote the intellectual and social development of children) is a direct application of AT (Cole 1996; Lalueza 2008). Similarly, Yrjö Engeström (Center for Activity Theory and Developmental Work Research, University of Helsinki) became a key translator of AT, making substantial contributions by retooling and applying it to practical concerns, such as strategic workplace management (Engeström 1987, 1999). This work was critical, as Vygotsky's publications were banned in the USSR from 1936 to 1956 (Bakhurst 1991). Vygotsky's cultural-historical approach was kept alive and developed by his students under very difficult circumstances until the thaw of the post-Stalin period. Today, a "third generation" of activity theorists are making important advances by taking AT in new directions, and applying its theoretical power to new fields of inquiry.

AT also made key advances in philosophy in the 1960s and 1970s, which make it a promising interlocutor for contemporary theories of the material turn. While AT is known largely for its contribution to psychology, its interventions in philosophy are only now beginning to be widely noted. For instance, as Andrey Maidansky and Vesa Oittinen write in their introduction to a new book that explores this tradition,

The "activity theory" in Soviet psychology, represented by Lev S. Vygotsky and Aleksei Leontiev, is now known around the world. However, 
its sibling, the philosophical activity theory, which arose among Soviet philosophers in the 1960s, remains virtually unknown outside Russia (Maidansky and Oittinen 2016: 1).

The "activity approach," as it developed in Soviet philosophy, reached its apogee in the postwar period, most notably in the work of Ilyenkov; however, as Sergey Mareev argues in his book, From the History of Soviet Philosophy: Lukács-Vygotsky-Ilyenkov (2008), there are significant continuities with the early period of the Revolution, as well as with Lenin and the early Lukács. It is particularly the insights of AT in the field of philosophy that I seek to bring to this conversation.

\section{The Material Turn: Rethinking the Human and the Nonhuman}

The material turn in contemporary philosophy signals at once a departure from the linguistic turn and a continuation of the latter's critique of Enlightenment conceptions of the human. By decentering the human, it seeks to free the lens of inquiry from its privileged position as the perspective of human subjects at the center of a world of objects. The material turn repositions the human as embedded in a larger living and thinking material world.

Pointing to new information-communication technologies and new biotechnologies, theories of the material turn note the continuities between humans and their environment (Haraway 2016, 1991; Pepperell 2009). Furthermore, the impact of new technologies has made it increasingly difficult to discern where the human ends and where the machine begins (Sugiyama and Vincent 2013; Katz 2003). As Sugiyama and Vincent write, "not only does the technology extend human body and sensory systems into the public domain, but it is also being incorporated into the human body and becoming part of a means of expressing identity and emotions" (2013: 2).

These new configurations result not only from biotechnologies, but also from the integration of machines into our practices. For example, recent scholarship has investigated the phenomenon of social robots"technological objects [that] arouse a sense of intersubjectivity in individuals, which prompts them to respond socially to such entities" (Halpern and Katz 2013: 19). Increasingly, it appears that today it is no longer the human that thinks with the aid of machines, but, as Longo claims, "it is always the human-computer unity that thinks" (2003: 27).

In addition to the increasing difficulties associated with the integration of new technologies into the body, Enlightenment conceptions of the human subject also stand accused of various forms of exclusion. For instance, Rosi Braidotti's recent book, The Posthuman begins with a pro- 
vocative claim: "Not all of us can say, with any degree of certainty, that we have always been human [...] Some of us are not even considered human now" (2013: 1). She reminds that humanity is not a self-evident category based on a timeless truth discovered by science, but is an exclusive club with a shifting membership, a club from which some have been excluded, and some continue to be excluded today. Essentialist notions of the human are understood as necessarily excluding those who may not be seen as having that essential quality that deems to define the human, such as the ability to think, the capacity to reason, the possession of property, and so on. Such essentialist conceptions of the human imply a nonhuman, an inhuman: the thoughtless, the irrational, the slave, the non-citizen, the refugee, and so on.

Alongside these critiques of Enlightenment conceptions of the subject, we also find critiques of Enlightenment conceptions of the object. Decentering the human also entails repositioning the nonhuman. As the human loses its central position as the subject in a world of objects, the nonhuman also loses its peripheral position as a world of objects. In the material turn, objects come alive. More accurately, the nonhuman appears not as a passive object, but as an actor as well.

For instance, perhaps in the most well known example-actor-network theory (ANT) - the nonhuman does not simply have things done to it or with it, but it also does. As Bruno Latour writes, "every time you want to know what a nonhuman does, simply imagine what other humans or other nonhumans would have to do were this nonhuman not present" (1992: 229). For Latour, technologies can prescribe certain behaviour to humans. He refers to this as a "prescription" written into technologies, which he defines as "the behaviour imposed back onto the human by nonhuman" (1992: 232). From an ANT perspective, the world of objects appears, in some ways, to be alive. ANT attributes agency and even responsibility to these technologies. As Latour responds to the infamous NRA slogan, "guns don't kill people, people do"; "It is neither people nor guns that kill. Responsibility for action must be shared among the various actants" (1999: 179-80). ANT has sought to capture this integration between humans and machines by theorizing a hybrid third entity resulting from the combination of human and machine. As Tamar Sharon writes, "For Bruno Latour (1999) for example, when a human shoots someone with a gun, it is the hybrid third entity, composed of a fusion of human and artifact, that is responsible for the action, rather than either of the individual "actants" that make up this network" (2014: 35).

In contrast to Latour, Braidotti is quite critical of how subjectivity appears to be "out of the picture" in science and technology studies; however, she shares with Latour a view of matter as having far more agency than "the object" in certain Enlightenment thought (2013: 42). Similar to ANT, new materialism also reanimates the nonhuman in the course of decentering the human. 
Drawing on Spinozist monism, new materialism rejects subject/object duality. Braditotti describes it as a "monistic philosophy of becoming [which] rests on the idea that matter, including the specific slice of matter that is human embodiment, is intelligent and self-organizing” (2013: 35). Barad adds: “'New materialism' as a term was coined by Manuel DeLanda and Rosi Braidotti in the second half of the 1990's. New materialism shows how the mind is always already material (the mind is an idea of the body), how matter is necessarily something of the mind (the mind has the body as its object), and how nature and culture are always already 'naturecultures' (Donna Haraway's term). New materialism opposes the transcendental and humanist (dualist) traditions that are haunting cultural theory" (Barad 2012: 48).

As Dolphijn writes, new materialism "explores a monist perspective, devoid of the dualisms that have dominated the humanities (and sciences) until today, by giving special attention to matter, which has been so neglected by dualist thought" (2012: 85). From a new materialist perspective, the human is always embedded in "the self-organizing or 'smart' structure of living matter” (Braidotti 2013: 57).

\section{Activity Theory: Anti-Essentialism and the Thinking Body}

Similar to theories of the material turn, AT represents a significant departure from essentialist conceptions of the human. It defines the human not as one who possesses an essential quality that all humans possess (such as the capacity to think or reason, and so on), but as a part of a larger whole: what makes one human is not a specific feature but one's role in the ensemble of social relations that comprise humanity (Vygotsky 1978; Marx and Engels 1991 [1846]). As Evald Ilyenkov writes in his innovative reading of Marx's Capital: "To comprehend a phenomenon means to establish its place and role in the concrete system of interacting phenomena in which it is necessarily realized, and to find out precisely those traits which make it possible for the phenomenon to play this role in the whole" (Ilyenkov 2008 [1960]: 177). In this case, to be human implies an already-existing humanity in the context of which one "awakens to consciousness" (Meshcheryakov 1974) as a human individual.

In contrast to essentialist conceptions of the human, AT posits the human subject as always embedded in socially meaningful activities oriented on a certain "object/ive"3 (Leontiev 1978; Engeström 1999; Kaptelinin 2005). Individuals may or may not be aware of the object/ive to which their separate actions contribute, which Leontiev calls the "true motive"

3 I use the term "object/ive" to capture the dual meaning of the Russian word, ob'ekt, which, in Leontiev's work, refers to both object and objective. 
of the activity (1978). The object/ive motivates the social activity, and calls to action individuals who participate in a complex division of labor. These social activities make intelligible the actions of individuals, at the same time as they shape those individuals. Because AT takes an activity (rather than an individual) as its "unit of analysis" (Vygotsky 1987: 46), individuals appear as nodes in a web of distributed cognition (Cole and Engeström 1993). Subjectivity appears dispersed across communities of practice, what "third generation" AT calls, activity systems (Engeström 1999).

This shift in the "unit of reference" (Braidotti 2013: 95) not only departs from essentialist conceptions of the subject, but also challenges essentialist conceptions of the object. From an AT perspective, the subject and the object are both embedded in activities, and cannot be understood in their isolation from those activities.

This approach closely parallels the emphasis on relation we find in the material turn in contemporary theory. For instance, Barad writes, "Relata do not preexist relations; rather relate-within-phenomena emerge through specific intra-actions" (2003: 815). A similar emphasis on relational reality is advanced in postphenomenology. As Don Ihde explains, "At the core of my analysis is an inter-relational or interactive ontology" (2010). Similarly, Peter-Paul Verbeek claims, "reality arises in relations" (2005: 113). Postphenomenology "does away with the idea that there is a pregiven subject in a pregiven world of objects, with a mediating relation between them. Rather, the mediation is the source of the specific shape that human subjectivity and the objectivity of the world can take in this specific situation" (Rosenberger and Verbeek 2015: 12).

What sets AT apart from postphenomenological and other theories of the material turn is how it grasps this relational reality. According to AT, the subject and object are also not pregiven. However, rather than finding ourselves embedded in "the self-organizing or 'smart' structure of living matter" (Braidotti 2013: 57), AT posits us as embedded in an ensemble of social practices, which gives rise to our conceptions, including our conceptions of living and non-living matter.

This approach is perhaps best articulated by Ilyenkov. A tragic figure, who took his own life in 1979 after years of state repression, he left behind a substantial collection of texts, many of which were published posthumously. In 1954, after publically declaring to the Chair of Dialectical Materialism at Moscow State University that in Marx there was no such thing as dialectical materialism, but only a materialist conception of history, Ilyenkov became a persona non grata. However, his bold defiance of Soviet diamat, which dominated Soviet philosophy from the early 1930s (Levant 2011), and his original reading of Marx earned him a position of leadership among a new generation of theorists, many of whom continue to develop his ideas today. In the 1960s and 1970s, he was widely regarded as the “philosophical mentor” (Bakhurst 1991: 218) of Soviet Activity Theory. 
Ilyenkov rejected Cartesian dualism in favor of what at first appears quite close to Braidotti's Spinozist monism. In Dialectical Logic, he writes,

There are not two different and originally contrary objects of investigation-body and thought-but only one single object, which is the thinking body [which] does not consist of two Cartesian halves-"thought lacking a body" and a "body lacking thought" [...] It is not a special "soul," installed by God in the human body as in a temporary residence, that thinks, but the body of man itself (Ilyenkov 1977: 18-19).

\section{As Vesa Oittinen notes,}

Ilyenkov stresses the methodological value of Spinoza's monism, which means a change for the better compared with the dualism of two substances in Descartes [...] The Cartesians had posed the whole question of the psycho-physical problem in a wrong way: they desperately sought to establish some kind of a causal relation between thought and extension, although such a relation simply doesn't exist. Thought and extension are simply two sides of the one and same matter (2005: 323).

However, there is a substantial difference between Ilyenkov's concept of the thinking body and the Spinozist monism that guides Braidotti.

Unlike other readers of Marx who turned from Hegel's dialectics to Spinoza's monism, Ilyenkov read Marx through both Hegel and Spinoza, producing an innovative understanding of the subject and the object that is neither monist nor dualist. Ilyenkov's thinking body does not refer to the physical body of the human (as in the thinking brain), nor does it refer to the material world as intelligent (Braidotti) or as having agency (Latour). Instead, Ilyenkov draws on Marx's concept of the inorganic body as that which thinks. Andrey Maidansky explains,

Ilyenkov insisted that Marx had in mind not the bodily organ of an individual Homo sapiens, growing out of his neck at the mercy of Mother Nature, but precisely the human head-a tool of culture, not of nature [...] Its body does not consist only of the brain, but also of any thing that is created by people for people. Products of culture are nothing but "the organs of the human brain created by the human hand, the reified power of knowledge," Marx writes in the Grundrisse (2005: 290).

Rather than the material brain or "'smart' structure of living matter" (Braidotti 2013: 57), Ilyenkov's thinking body refers to something else, another type of matter.

In contrast to the matter referred to in new materialism, and in the material turn more broadly, Ilyenkov focuses on the material of human activity. For Ilyenkov, thinking is an attribute not of the matter of the 
physical brain, or of the material world more broadly (as in Spinoza and Braidotti), but of the objective material reality of social practices in which brains are embodied and bodies are embedded (Ilyenkov 2012 [2009]). Taking seriously Marx's early writings, especially his Theses on Feuerbach, where Marx claims that "The chief defect of all hitherto existing materialism - that of Feuerbach included-is that the thing, reality, sensuousness, is conceived only in the form of the object of contemplation, but not as sensuous human activity, practice" (Marx 1969 [1888]), Ilyenkov examines the material world as a form of human activity.

According to Ilyenkov, human activity gives rise to ideal representations of the material world, which comprise the sum of human knowledge, our social norms, laws and customs - immaterial phenomena that are codified and practiced (Ilyenkov 2012 [2009]; Levant 2014). Although social in their nature, human representations of the material world are themselves "peculiarly" objective (i.e., material). As Keti Chukhrov writes, "In this case, there is no split between body and idea, since the ideal manifests itself via material externality and occupies the 'body' and its empirical existence. Such an understanding of the ideal does not position it as something sublime or as superseding reality" (2013). The ideal exists outside the individual, and confronts her as a "special reality" as "all historically formed and socially legitimized human representations of the actual world [...] 'things,' in the body of which is tangibly represented something other than themselves" (Ilyenkov 2009: 14). This reflection of things in other things is not a mental projection onto the material world; rather, it exists objectively in the same physical space as the matter it represents, namely in the material activity of human beings. Consequently, ideal representations of material objects always involve the activities into which those objects are incorporated. Ilyenkov writes, "Since man [sic] is given the external thing in general only insofar as it is involved in the process of his activity, in the final product-in the idea-the image of the thing is always merged with the image of the activity in which this thing functions. That constitutes the epistemological basis of the identification of the thing with the idea, of the real with the ideal" (Ilyenkov 1977: 162). Similar to new materialism, Ilyenkov's historical materialism offers a corrective to the problem of relativism. At the same time, it also sidesteps a crude, pre-Marxist, materialism, what Lenin called in his 1916 Philosophical Notebooks "silly materialism" (Ilyenkov 2009: 25-26).

Rejecting the Althusserian assertion of an epistemological break between early and mature Marx, Ilyenkov argues that Marx's critique of the value-form in classical political economy, as articulated in Capital, was an application of a deeper insight that he had developed in his early philosophical writings. According to Marx, the value-form of a commodity is ideal-it has no material properties, and it bears absolutely no relation to the material properties of the commodity itself. Ilyenkov writes: 
This is a purely social form, completely indifferent to any sensuously perceptible material of its "incarnation" [voploshcheniia], of its "materialization." The value-form is absolutely independent of the characteristics of the "natural body" of the commodity in which it "dwells" [vseliaetsia], the form in which it is represented (Ilyenkov 2009: 21).

Just as Marx was able to grasp value as neither a property of the commodity nor a mental projection onto the commodity, but rather as labor, Ilyenkov grasps the ideal in general as human activity in general, that is, as the process of the human transformation of the material world:

The real materialist solution to the problem in its proper formulation (already noted by Hegel) was found, as we know, by Marx, who had in mind an entirely real process, specifically inherent to human life-activity: the process by which the material life-activity of social man [sic] begins to produce not only a material, but also an ideal product, begins to produce the act of idealisation of reality (the process of transforming the "material" into the "ideal"), and then, having arisen, the "ideal" becomes a critical component of the material life-activity of social man, and then begins the opposite process - the process of the materialization (objectification, reification, "incarnation") of the ideal (Ilyenkov 2009: 18).

In contrast to new materialism, Ilyenkov focuses our attention onto historically formed material practices, to which he would attribute the apparent "agency" of objects. Human agency is reified in these objects, which acquire a fetishized form of appearance. In other words, the "'smart" structure of living matter" appears from this perspective as reified and fetishized human activity. Similarly, objects do not appear to have agency in the same way as they appear in ANT. Rather than things possessing agency, objects appear as social artifacts, which become meaningful in the context of a community of practice. Their "agency" is how their effect registers in ANT. In contrast, AT would not attribute a shared responsibility for gun deaths to gun and person. While the presence of guns is obviously a prerequisite for gun violence, guns are not held to account because they are not subjectified. Instead, "responsibility" is distributed across communities of practice responsible for the presence of guns and for the other motivating factors behind the activities leading to gun deaths (Kaptelinin and Nardi 2006).

Furthermore, from an AT perspective, the material turn in contemporary philosophy tends to minimize and, in some respects, to occlude the impact of human activity. In the course of decentering the human in theory, these new trends may inadvertently be cementing existing anthropocentrism in practice. In contrast, AT would see anthropocentrism not as a consequence of inadequate theory, but as a consequence of specific practices. These anthropocentric practices give rise to (and subsequently 
reproduce) anthropocentric theory. Consequently, the material turn may, in fact, be simply shifting our attention from these practices, and instead accepting their animation of matter as a property of matter itself.

\section{Conclusion: Anthropocentrism or Capitalocentrism?}

From an AT perspective, we do not live in a human-centered world. On the contrary, the center is currently occupied not by the human, but by the human's creation, namely capital. In a similar vein, Jason W. Moore challenges the notion of the Anthropocene broadly discussed today, ${ }^{4}$ and proposes to call the current period the Capitalocene: "Are we really living in the Anthropocene, with its return to a curiously Eurocentric vista of humanity, and its reliance on well-worn notions of resource- and technological-determinism? Or are we living in the Capitalocene, the historical era shaped by relations privileging the endless accumulation of capital?" (2015: 135). Increasingly, human society is becoming uninhabitable for humans and more of a home for capital. Like Frankenstein's monster, capital is a human creation, which comes to dominate its makers. As our environment becomes more habitable for capital, it becomes less habitable for the human. We can see this most clearly when we contrast the increasing poverty of the human with the ascendancy of the commodity, the "cell-form" of capital (Marx 1887 [1867]).

In this sense, matter is smart, as it appears to resemble the features of a living and thinking being. However, as Marx (1887 [1867]) reminds us, the life of capital is "vampire-like"-it is animated by the activity of human beings who are possessed by their possessions. Consequently, it appears that the material turn in contemporary philosophy may be conflating the object form with the commodity form, and to attributing the properties of the commodity form to the object itself. This fetishism of the commodity produces a conception of the material world as smart, at the same time as it occludes the impact of human activity on that world.

4 John Bellamy Foster explains in his introduction to Ian Angus's recent book, Facing the Anthropocene: Fossil Capitalism and the Crisis of the Earth System: "The Anthopocene, viewed as a new geological epoch displacing the Holocene epoch of the last 10,000 to 12,000 years, represents what has been called an 'anthropogenic rift' in the history of the planet. Formally introduced into the contemporary scientific and environmental discussion by climatologist Paul Crutzen in 2000, it stands for the notion that human beings have become the primary emergent geological force affecting the future of the Earth System" (Angus 2016: 1). This is a contested term, as some scholars question when the Holocene ended and the Anthropocene began, arguing that the Anthropocene started much earlier. However, Jason W. Moore (2015) persuasively argues (as I explain below) that it is not the human that occupies the center today, but capital. Hence, he calls this period the Capitalocene. 
Part of the reason for such different understandings of matter between the materialism of the material turn and the historical materialism of AT has to do with differences in their critiques of dualist conceptions of the subject and the object. In contrast to the material turn, which critiques dialectics in the same breath as dualism (Sharon 2014; Braidotti 2013), AT is critical of dualism, but not of dialectics. Quite the opposite: it sees dialectics as anti-dualist and anti-reductionist, and would see monism as another form of reductionism. From an AT perspective, monism in no way overcomes dualism; it simply collapses the subject/object duality by subjectifying the object. In contrast, AT approaches dualism as a practical problem that cannot be solved in theory. In fact, such "solutions" tend to result in either idealism or crude materialism. AT, on the other hand, refocuses our attention from our conceptions of reality to our practices, to the activity circuits through which we move. It invites us to rethink the subject/object dualism not by subjectifying the object, but by recasting the subject and the object as moments embedded in social practices that must be transformed.

AT articulates a different type of materialism, where "sensuous human activity" (Marx 1969 [1888]) is understood as a material phenomenon with a "peculiar objectivity." It illuminates this "special reality" by grasping the subject and the object as moments in the life of the thinking body, as activities in which individuals awaken to consciousness.

It is no accident that AT first emerged in the context of developmental psychology, as it unfreezes matter, and resituates it the context of historical development, hence illuminating the temporal (i.e., historical) dimension where activity becomes visible. What had once been a freezeframe in a film, now appears as a moment in a developing story with actors, acting in an objective world, according to the material properties of that world, as they have emerged in the ideal forms that motivate human activity (Ilyenkov 2012 [2009]).

Taking human activity as its unit of analysis yields a conception of the human and the nonhuman that shares much of the critique of essentialism and dualism we find in the material turn. However, it approaches the problem of anthropocentrism differently: not as a product of humanistic theory inherited from the Enlightenment, but as the consequence of a specific method of organizing human activity-the capitalist mode of production. AT illuminates capital lurking in the shadow of the human. It identifies the specific organization of human activity that produces not a human-centric world, but a world where the unprecedented power of the human is driven to act against the human.

Similar to the material turn, AT rejects a reified notion of matter, as a collection of objects in a human-centric world; however, it also rejects a fetishized notion of matter that attributes properties to the nonhuman, which arise from human activity. In contrast, AT shifts our analysis from smart matter to the thinking body. It calls for a reconsideration of our 


\section{Smart Matter and the Thinking Body}

conceptions of the human and the nonhuman, and the activities that produce these conceptions. It invites us to examine these activities as the units in which the human and the nonhuman become intelligible. And most importantly, it serves as a call to action: it insists that the human and the nonhuman are not pregiven or fixed, nor are they slices of smart matter-they are moments in the saga of our social practices, which have discernible patterns that can be understood and can be changed.

\section{Bibliography}

Angus, Ian (2016). Facing the Anthropocene: Fossil Capitalism and the Crisis of the Earth System. New York: Monthly Review Press.

Bakhurst, David (1991). Consciousness and Revolution in Soviet Philosophy: From the Bolsheviks to Evald Ilyenkov. Cambridge: Cambridge University Press.

Barad, Karen (2003). "Posthumanist Performativity: Toward an Understanding of How Matter Comes to Matter.” Signs 28.3: 801-31.

Barad, Karen (2007). Meeting the Universe Half Way: Quantum Physics and the Entanglement of Matter and Meaning. Durham, NC: Duke University Press.

Barad, Karen (2012). “Interview with Karen Barad.” In New Materialism: Interviews \& Cartographies, eds. Rick Dolphijn and Iris van der Tuin, 48-71. Ann Arbor: Open Humanities Press.

Benjamin, Walter (2003). “On the Concept of History.” In Selected Writings, Vol. 4: 19381940 [1940], 389-400. Cambridge, MA: Harvard University Press.

Bøttcher, Louise, and Jesper Dammeyer (2016). Development and Learning of Young Children with Disabilities: A Vygotskian Perspective. London: Springer.

Braidotti, Rosi (2013). The Posthuman. Cambridge: Polity Press.

Chukhrov, Keti (2013). "Epistemological Gaps between the Former Soviet East and the 'Democratic' West.” e-flux. 41.1 http://www.e-flux.com/journal/41/60226/epistemological-gaps-between-the-former-soviet-east-and-the-democratic-west/

Cole, Michael (1996). Cultural Psychology: A Once and Future Discipline. Cambridge, MA: Harvard University Press.

Cole, Michael and Yrjö Engeström (1993). “A Cultural-Historical Approach to Distributed Cognition.” In Distributed Cognitions: Psychological and Educational Considerations, ed. Gavriel Salomon, 1-46. New York: Cambridge University Press.

De Smet, Brecht (2015). Gramsci on Tahrir: Revolution and Counter-revolution in Egypt. London: Pluto Press.

Dolphijn, Rick, and Iris van der Tuin, eds. (2012). New Materialism: Interviews \& Cartographies. Ann Arbor: Open Humanities Press.

Engeström, Yrjö (1987). "Learning by Expanding. An Activity-Theoretical Approach to Developmental Research,” PhD diss. Univeristy of Jyväskylä.

Engeström, Yrjö (1999). “Activity Theory and Individual and Social Transformation.” In Perspectives on Activity Theory, eds. Yrjö Engeström and Reijo Miettinen, 19-38. Cambridge: Cambridge University Press. 
Engeström, Yrjö, and Reijo Miettinen, eds. (1999). Perspectives On Activity Theory. Cambridge: Cambridge University Press.

Halpern, Daniel, and James Katz (2013). "Close But Not Stuck: Understanding Social Distance in Human-Robot Interaction Through a Computer Mediation Approach.” In Social Robots and Emotion: Transcending the Boundary Between Humans and ICTs, eds. Satomi Sugiyama and Jane Vincent, 17-34. Intervalla: Platform for Intellectual Exchange, Vol.1; https://www.fus.edu/intervalla/volume-1-social-robots-and-emotion-transcending-the-boundary-between-humans-and-icts

Haraway, Donna (1991). “A Cyborg Manifesto: Science, Technology, and Socialist- Feminism in the Late Twentieth Century.” In Simians, Cyborgs and Women: The Reinvention of Nature, ed. Donna Haraway, 149-81. New York: Routledge.

Haraway, Donna (2016). Staying with the Trouble: Making Kin in the Chthulucene. Durham: Duke University Press.

Hasse, Cathrine (2015). An Anthropology of Learning: On Nested Frictions in Cultural Ecologies. London: Springer.

Hedegaard, Mariane, and Marilyn Fleer (2008). Studying Children: A Cultural-Historical Approach. England: Open University Press.

Ihde, Don (2010). “Interview with Don Ihde.” Figure/Ground. http://figureground.org/ interview-with-don-ihde/

Ilyenkov, Evald (1974). Dialekticheskaja logika [Dialectical logic]. Moscow: Politizdat.

Ilyenkov, Evald (1977). Dialectical Logic: Essays on Its History and Theory [1974]. Trans. H. Campbell Creighton. Moscow: Progress.

Ilyenkov, Evald (1982). Leninist Dialectics and the Metaphysics of Positivism: Reflections on V.I. Lenin's Book “Materialism and Empirio-criticism” [1979]. Trans. Frederick Choate. London: New Park Publications.

Ilyenkov, Evald (2008). The Dialectics of the Abstract and the Concrete in Marx's Capital [1960]. Delhi: Aakar Books.

Ilyenkov, Evald (2009). “Dial'ektika ideal'nogo” [Dialectics of the ideal]. Logos. 69.1: 6-62.

Ilyenkov, Evald (2012). “Dialectics of the Ideal” [2009]. Trans. Alex Levant. Historical Materialism 20.2: 149-93.

Kaptelinin, Victor (2005). “The Object of Activity: Making Sense of the Sense-Maker.” Mind, Culture and Activity. 12.1: 4-18.

Kaptelinin, Victor and Bonnie Nardi (2006). Acting With Technology: Activity Theory and Interaction Design. Cambridge, MA: MIT Press.

Katz, James E. ed. (2003). Machine that Become Us: The Social Context of Personal Communication Technology. New Brunswick and London: Transaction Publishers.

Lalueza, José Luis, Isabel Crespo, and Marc Bria. (2008). "Microcultures, Local Communities, and Virtual Networks." In Handbook of Research on Digital Information Technologies, 117-30. Hershey, PA: IGI Global.

Latour, Bruno (1992). "Where Are the Missing Masses? The Sociology of a Few Mundane Artifacts.” In Shaping Technology/Building Society: Studies in Sociotechnical Change, eds. Wiebe E. Bijker and John Law, 225-58. Cambridge, MA: MIT Press.[

Latour, Bruno (1999). Pandora's Hope: Essays on the Reality of Science Studies. Cambridge, MA: Harvard University Press. 


\section{Smart Matter and the Thinking Body}

Latour, Bruno (2005). Reassembling the Social: An Introduction to Actor-Network-Theory. Oxford: Oxford University Press.

Law, John (2010). “The Material of STS.” In The Oxford Handbook of Material Culture Studies, eds. Mary Caroline Beaudry and Dan Hicks, 171-86. Oxford: Oxford University Press.

Leontiev, Aleksey N. (1975). Deyatel'nost, soznanie, lichnost' [Activity, consciousness, and personality]. Moskva: Politizdat.

Leontiev, Aleksey N. (1978). Activity, Consciousness, and Personality. New York: Prentice-Hall.

Levant, Alex (2008). The Soviet Union in Ruins. Saarbrucken: VDM Verlag.

Levant, Alex (2011). "Towards a History of Creative Soviet Theory: From the History of Soviet Philosophy: Lukács-Vygotsky-Ilyenkov by Sergey Mareev.” Historical Materialism 19.3: 176-89.

Levant, Alex (2014). “E.V. Ilyenkov and Creative Soviet Marxism: Introduction to Dialectics of the Ideal.” In Dialectics of the Ideal: Evald Ilyenkov and Creative Soviet Marxism, eds. Alex Levant and Vesa Oittinen, 3-24. Leiden: Brill.

Longo, G. (2003). "Mediating the Human Body: Technology, Communication, and Fashion.” In Body and Technology: Continuity or Discontinuity, eds. Leopoldina Fortunati, James Katz, and Raimonda Riccini, 23-29. Mahwah, NJ: Lawrence Erlbaum.

Maidansky, Andrey (2005). “Metamorphoses of the Ideal.” Studies in East European Thought 57: 289-304.

Maidansky, Andrey, and Vesa Oittinen, eds. (2016). The Practical Essence of Man: The "Activity Approach" in Late Soviet Philosophy. Leiden: Brill.

Mareev, Sergey (2008). Iz Istorii Sovetskoi Filosofii: Lukach-Vygotskii-Il'enkov [From the history of Soviet philosophy: Lukács-Vygotsky-Ilyenkov]. Moscow: Kul’turnaia revoliutsiia.

Marx, Karl (1859). A Contribution to the Critique of Political Economy. .<www.marxists. org/archive/marx/works/1859/critique-pol-economy/index.htm>.

Marx, Karl (1887). Capital: Critique of Political Economy [1867]. <www.marxists.org/archive/marx/works/1867-c1/index.htm>.

Marx, Karl (1969). Theses on Feuerbach [1888]. Trans. W. Lough. <http://www.marxists. org/archive/marx/works/1845/theses/theses.pdf>.

Marx, Karl, and Friedrich Engels (1991). The German Ideology [1846]. New York: International Publishers.Meshcheryakov, Alexander (2009). Awakening to Life: On the Education of Deaf-blind Children in the Soviet Union. Pacifica, CA: Marxists Internet Archive.

Meshcheryakov, Alexander (1974). Slepogluhie deti. Razvitie psihiki v protsesse formirovaniya povedeniya [Deaf-blind children: The development of the mind in the process of forming behaviour]. Moscow: Pedagogy.

Meshcheryakov, Alexander (2009). "Awakening to Life: On the Education of Deaf-blind Children in the Soviet Union.” Marxists Internet Archive. https://www.marxists. org/archive/meshcheryakov/awakening/index.htm.

Moore, Jason W. (2015). Capitalism in the Web of Life: Ecology and the Accumulation of Capital. London: Verso. 
Nissen, Morten, and Katrine Barington (2016). "Numbers: User-Driven Standards and Manageable Nothingness.” In Nothingness: Philosophical Insights into Psychology, eds. Jytte Bang and Ditte Winther-Lindqvist. London: Transaction Publishers.

Oittinen, Vesa (2005). “Evald Il'enkov as interpreter of Spinoza.” Studies in East European Thought 57: 319-38.

Pepperell, Robert (2009). The Posthuman Condition: Consciousness Beyond the Brain. Bristol: Intellect Books.

Rosenberger, Robert, and Peter-Paul Verbeek, eds. (2015). Postphenomenological Investigations: Essays on Human-Technology Relation. Lanham: Lexington Books.

Sawchuk, Peter H. (2007). “Understanding Diverse Outcomes for Working-Class Learning: Conceptualising Class Consciousness as Knowledge Activity.” The Economic and Labour Relations Review 17.2: 199-216.

Sharon, Tamar (2014). Human Nature in an Age of Biotechnology: The Case for Mediated Posthumanism. London: Springer.

Stetsenko, Anna (2005). "Activity as Object-Related: Resolving the Dichotomy of Individual and Collective Planes of Activity.” Mind, Culture, and Activity. 12.1: 70-88.

Stetsenko, Anna (2013). “The Challenge of Individuality in Cultural-Historical Activity Theory: "Collectividual” Dialectics from a Transformative Activist Stance." Outlines: Critical Practice Studies 14.2: 7-28.

Sugiyama, Satomi, and Jane Vincent eds. (2013). Social Robots and Emotion: Transcending the Boundary Between Humans and ICTs. Intervalla: Platform for Intellectual Exchange, Vol.1. https://www.fus.edu/intervalla/volume-1-social-robots-andemotion-transcending-the-boundary-between-humans-and-icts.

Verbeek, Peter-Paul (2005). What Things Do: Philosophical Reflections on Technology, Agency, and Design. University Park: Pennsylvania State University Press.

Vygotsky, Lev (1978). Mind in Society: The Psychology of Higher Mental Functions. Cambridge, MA: Cambridge University Press. 